\title{
CONTRIBUTOS REFLEXIVOS PARA O ESTUDO DAS RELAÇÕES ENTRE A EDUCAÇÃO E O DESENVOLVIMENTO
}

\author{
Artur Carlos Crespo Martins Cabugueira*
}

\begin{abstract}
Neste artigo desenvolvemos alguns pontos relativos à temática das relações entre a educação e o desenvolvimento, dando especial destaque às questões do chamado capital humano.

Começamos por fazer uma revisão das principais ideias e teorias sobre o problema, desde os Mercantilistas até aos autores contemporâneos, referindo-nos com especial ênfase à emergência, nos anos 60, da teoria do capital humano.

Apresentamos as razões do surgimento desta teoria, expomos os argumentos utilizados pelos seus defensores, nomeadamente os relacionados com as contribuições das quais emergiram os novos modelos neoclássicos de crescimento, de acordo com os quais ofactor decisivo do crescimento económico é a inovação endógena, sendo esta actividade inovadora gerada no interior da economia e, ela própria, influenciada pela dotação da economia em capital humano.

Por outro lado, apresentamos também as razões em que se baseiam as críticas dos autores que rejeitam ou aceitam condicionalmente a importância do capital humano no desenvolvimento económico. Expomos, assim, algumas das críticas mais correntemente emitidas, assim como referenciamos os requisitos $e$ as condições que frequentemente são sugeridas, consideradas imprescindiveis para que a educação possa ser um, entre outros factores que exercem uma influência positiva em beneficio da
\end{abstract}

\footnotetext{
* Professor auxiliar da Universidade de Trás-os-Montes e Alto Douro (Extensão de Chaves).
} 
sociedade. Concluimos fazendo um balanço de todas as opiniões expostas, explicitando a nossa opinião pessoal relativamente a esta temática cada vez mais actual.

Palavras-chave: Capital humano, desenvolvimento, inovação, educação, modernização, rendimento

\section{INTRODUÇÃO}

Assistimos durante as últimas décadas a um interesse cada vez maior pelos aspectos sociais e económicos da educação, sendo várias as explicações que se podem dar e têm sido dadas, para explicar este fenómeno. Uma delas centra-se no considerável aumento do volume da actividade educativa, até ao ponto de, hoje em dia, a educação absorver uma das maiores fatias dos orçamentos em quase todos os países. Outra razão reside no reconhecimento de que a educação tem uma influência significativa nas oportunidades sociais, afectando a mobilidade interclasses, as fontes de rendimentos, a qualificação profissional ou a distribuição da riqueza na sociedade. Uma terceira razão é a que surge de, a partir do fim da $2^{\mathrm{a}}$ Guerra Mundial, se terem enfatizado os aspectos relacionados com o crescimento económico, o desenvolvimento económico e social, o bem-estar, a modernização, etc., com o que a educação passou a desempenhar um papel importante, sob a perspectiva geral de responder nos seus processos aos modelos da sociedade em evolução. Outras muitas razões aludem à situação defícitária dos países subdesenvolvidos ou em vias de desenvolvimento, assim como também aos critérios de avanço e progresso técnico, às necessidades de planificação educativa nos processos gerais de planificação social, ao avanço da democratização e participação comunitária, etc.

No decurso da história recente, e até há bem pouco tempo, as modificações experimentadas pelos sistemas educativos foram influenciadas, essencialmente, pelo carácter reprodutivo dos investimentos realizados. A função da educação era, sobretudo, a de abastecer satisfatoriamente o mercado de trabalho, colocando-se em funcionamento algumas "linhas de montagem" com o objectivo de produzir os diversos tipos de "homens ensinados" de que a sociedade necessitava.

Nos países industrializados tiveram lugar, durante a década de 1960, grandes reformas estruturais dos sistemas de ensino, em consonância com 
o rápido crescimento económico que então se viveu. Todavia, assistiu-se em seguida a uma assinalável desaceleração dos investimentos em educação na sequência da crise económica iniciada no começo dos anos 1970.

Interessa, assim, analisar como é que se formulou, em diferentes momentos e diferentes áreas da política social e económica, o problema do contributo da educação para o funcionamento do sistema económico e social.

\section{EVOLUÇÃO DO PENSAMENTO RELATIVAMENTE AO CONTRIBUTO DA EDUCAÇÃO PARA O DESENVOLVIMENTO}

\subsection{O Pensamento desde os Mercantilistas até à $2^{\mathrm{a}}$ Guerra Mundial}

Sabe-se que os primeiros estudos destinados à análise do papel da educação no desenvolvimento surgiram na linha da importância que os antigos economistas concederam à educação na produtividade do trabalho. Assim, os mercantilistas analisaram a influência da formação dos trabalhadores na produtividade total, sendo abundantes as alusões que se fazem sobre este problema em obras de autores como W. Petty, D. Hume e noutros economistas pré-clássicos.

Por seu lado, os economistas clássicos centram a sua atenção no factor trabalho, destacando com toda a evidência as aptidões que o elemento humano - o trabalhador e a sua formação - traziam para a produtividade do trabalho, como se aprecia nas obras de A. Smith, T. R. Malthus, J. S. Mill, A. Marshall, etc.

O fundador da Escola Clássica (A. Smith, 1776) deu à educação um lugar preponderante nas suas discussões na obra que se tornou universalmente famosa - A Riqueza das Nações. Smith tratou a educação como moralista e professor e como reformador (desejava dinamizar o ensino em bases competitivas, para torná-lo mais eficiente, da mesma maneira que preconizava o "laissez-faire, laissez-passer" no plano económico).

Acentuou a importância da educação ${ }^{1}$ como meio de contrabalançar os desumanos resultados da divisão do trabalho. Os seus discípulos também encararam a educação nacional como a base da actividade económica e 
do progresso e como o meio de gerar "hábitos previdentes e ordeiros". Aliás, dentro desse contexto é que Robert Malthus, David Ricardo e John Stuart Mill deram destaque à educação, ou seja, consideraram-na como criadora de hábitos de prudência, economia e auto-aperfeiçoamento. Para os dois primeiros, a educação seria, sobretudo, meio de incutir hábitos de limitação da família. O terceiro - talvez o melhor expositor da Escola Clássica -, ao resumir com perfeição as suas teorias, amplia esse enfoque nos Princípios de Economia Política, em 1848, onde expressamente diz: "para o propósito, pois, de alterar os hábitos da classe trabalhadora [...]. A primeira necessidade é uma efectiva educação nacional dos filhos dos trabalhadores [...]. Pode-se afirmar, sem receio, que o objectivo de toda a aprendizagem intelectual das massas do povo deve ser o cultivo do bom senso, qualificá-las para a formação de salutar julgamento prático das circunstâncias que os rodeiam" (J. S. Mill, 1867). E afirma que é de interesse público que todos recebam educação primária e alguns "espíritos superiores" uma educação melhor ${ }^{2}$.

E enquanto Ricardo não se preocupava com o custeio da educação, Malthus apoiava o esquema de Smith em relação às escolas paroquiais, típicas do sistema escocês e que vinham dando bons resultados há alguns séculos. Por sua vez Mill, apesar de rejeitar a intervenção do Estado, admitia que "a educação é daquelas coisas que, em princípio, se pode admitir que o governo proporcione ao povo".

Coube, porém, ao professor Alfred Marshall relacionar a educação com as necessidades da força de trabalho, defender a educação técnica, tanto para as classes trabalhadoras como para as classes médias, que até então confiavam na "estreita faixa da educação proporcionada pela antiga escola secundária". Deu ênfase à educação geral, porque torna o empregado "mais inteligente, mais decidido", porque é "importante meio de produção de riqueza material, ao mesmo tempo que, encarada como fim em si mesma, não é inferior a nenhum daqueles que podemos colocar ao serviço da produção de riqueza material. Considerou a educação o mais valioso capital que se investe nos seres humanos e chegou a apresentar minuciosa demonstração matemática dos lucros da educação (A. Marshall, 1890) ${ }^{3}$.

E assim, desde A. Smith até A. Marshall, a educação - especialmente a educação pública, mantida pelo Governo - mereceu a atenção dos economistas. Embora usando expressões diferentes, todos eles a encararam como agente de promoção social, de auto-aperfeiçoamento, de criação de riquezas - em suma, como agente de desenvolvimento 
económico. Karl Marx, apesar de se opor às concepções dos clássicos e de iniciar contra a doutrina liberal e individualista uma violenta reacção de que o Capital é o marco fundamental -, vê na educação, tal como Smith, um meio de atenuar as consequências desfavoráveis para a classe trabalhadora.

Para Marx, "a combinação do trabalho produtivo, paga com a educação mental, com os exercícios corporais e com a aprendizagem politécnica, elevará a classe operária a um nível bem superior ao das classes burguesa e aristocrática" (K. Marx, 1846).

Posteriormente, as correntes neoclássicas, mais interessadas em optimizar a afectação dos recursos disponíveis, não encararam a educação como forma de investimento, aspecto que só viria a ser retomado nas décadas de 50 e 60 .

\subsection{O Pensamento nos anos posteriores à $2^{\mathrm{a}}$ Guerra Mundial. A Teoria do Capital Humano}

Só depois de 1950 é que os processos de investigação explícitos e sistemáticos sobre a influência que a educação poderia ter sobre o desenvolvimento é que voltam a ganhar fôlego.

Segundo Garcia de Diego (1975: 5-14), "este aparente retrocesso no estudo do factor mais importante do desenvolvimento económico deve-se a várias razões. Por um lado, a resistência em assimilar o factor humano ao capital físico. Por outro, o facto de que os factores visíveis da produção eram as matérias-primas, as máquinas e o homem, como elementos materiais e medíveis. Por outro lado, a dificuldade de medir e expressar quantitativamente a formação era um obstáculo praticamente insuperável".

$\mathrm{Na}$ etapa do pós-guerra e anos posteriores, uma série de acontecimentos, tais como o chamado "milagre alemão" ou o pouco êxito obtido nas ajudas a países subdesenvolvidos, levaram os economistas a pensar que, em ambos os casos, êxito ou fracasso poderiam ser devidos à presença ou ausência, para os países considerados, de elementos diferentes aos tradicionalmente aceites como factores de produção.

No início da década de 50, deu-se uma verdadeira explosão de estudos sobre a mobilidade social, nos quais se realçava a educação como um dos seus agentes mais importantes. Procurava mostrar-se que, pela educação, os indivíduos ascendiam na escala de prestígio da sociedade estratificada, 
o que resultaria numa mudança para a sociedade, já que a estratificação social se apresentava menos rígida.

Nos anos 50, despontaram os trabalhos que procuram mostrar a educação como mecanismo de mobilidade social, considerada como uma aproximação de mudança social. Esse período configura-se dentro dos seguintes parâmetros internacionais:

- Dá-se a reestruturação da "ordem social", totalmente abalada com a $2^{\text {a }}$ Guerra Mundial, através do fortalecimento do bloco socialista, da configuração dos sistemas capitalista e socialista em áreas definidas e do surgimento de um número crescente de antigos países coloniais, que parecem relativamente independentes, política e economicamente, dos dois campos em que se dividiu o mundo do pós-guerra;

- No domínio político e social nota-se uma grande preocupação pela legitimação da social-democracia (também chamada de liberalismo radical e de socialismo moderado), esmagada e ameaçada, de um lado, pela ideologia fascista de passado recente e, de outro, pelo socialismo soviético, fortalecido pela $2^{\mathrm{a}}$ Guerra Mundial e difundido nos países de Leste;

- Quanto à educação, ela é concebida como uma "técnica social", um instrumento imprescindível para formar cidadãos democráticos, que permitam o funcionamento de uma sociedade democrática planificada.

Assim, nos estudos da década de 50, há uma maior ênfase na mobilidade social ligada à educação, mas como o essencial é mostrar uma fluidez no sistema de estratificação social, nem sempre é unicamente considerado o papel da educação. Alguns procuram observar influências de outras variáveis, para além da educacional, que contribuam para o processo de mobilidade, como a imigração, a fertilidade, o talento individual, enquanto outros se limitam a discutir técnicas para medir a mobilidade social.

Apesar de alguns trabalhos do período de 50-60 já empregarem uma linguagem económica, ela é menos frequente do que no período posterior, onde se coloca a educação como um investimento e onde se fala a cada instante de produto, taxa de retorno, consumo, procura e oferta.

A década de 60 apresenta, além das peculiaridades históricas de década de 50 já descritas, mais alguns aspectos típicos que iremos ressaltar, tendo em vista localizar os estudos sobre os aspectos económicos da educação. 
Internacionalmente, os sistemas capitalista e socialista consolidam-se em áreas definidas. A situação económica é configurada por uma tendência para a efectivação de um sistema capitalista monopolista (em termos de acumulação de capital), no qual se procura manter uma relativa estabilidade, preocupando-se em evitar as possíveis crises cíclicas.

A par desta situação, é de observar que o crescimento económico surpreendente na Alemanha e Japão do pós-guerra era praticamente inexplicável segundo a economia clássica. Os factores de produção terra, capital e trabalho, como foram utilizados para explicar o crescimento nos primórdios do capitalismo, mostraram-se neste casos (os "milagres" alemão e japonês) como insuficientes. Houve necessidade de criar "novos" conceitos adequados à "nova" realidade. A partir de 1960, procura estudar-se a educação dentro duma "perspectiva mais económica. A educação passa a ser considerada como um requisito para o desenvolvimento económico". A mobilidade social, apesar de não ser totalmente omitida, nesta fase, passa para um segundo plano. Surgiu então o conceito de capital humano, humano porque se acha configurado no homem e capital porque é fonte de satisfações futuras, futuros rendimentos ou ambos (Schultz, 1973: 63-64).

É a partir daí que começa a dar-se ênfase à visão económica da educação, pois seria a qualificação da mão-de-obra um dos possíveis factores que influenciaram a espantosa reconstrução e continuidade do sistema capitalista.

Politicamente, persistem ainda os ideais da democracia liberal, mas vão perdendo a sua força na medida em que o Estado procura sobretudo sustentar o desenvolvimento. Com a divisão internacional do trabalho, os Estados passam a interferir directamente nos assuntos económicos. A democracia liberal cede aos Estados fortes (capitalistas) que passam a planificar o progresso e o bem-estar social, interferindo directamente na esfera de produção. Traçadas estas linhas gerais, podemos verificar uma afinidade entre os interesses económicos, políticos e sociais da época e da produção científica na área da educação. Nos anos 50 , que se caracterizaram por uma demonstração de liberalismo e democratização, constatamos a maior incidência de pesquisas sobre a mobilidade educacional. No segundo período (anos 60), em que se dá ênfase sobretudo a um desenvolvimento sem crises, nota-se a maior frequência de trabalhos com um enfoque económico da educação. Por que se verificou esta viragem? Os motivos que talvez tenham influenciado a mudança de enfoque científico foram a modificação das formas de legitimação do regime. Essa modificação dá-se inicialmente em termos 
políticos (ideologia democrática) e posteriormente em termos económicos (ideologia desenvolvimentista).

Quando a democracia revela um regime político incapaz de manter e fortalecer as bases do capitalismo, ela é abandonada a favor de regimes políticos "fortes". A partir de 60, então, a ideologia democrática é substituída por uma ideologia desenvolvimentista que preenche a mesma função: assegurar a continuidade e o fortalecimento do modo de produção capitalista, num período de reorganização mundial depois do abalo sofrido pela $2^{\mathrm{a}}$ Guerra Mundial.

Destacaremos, de seguida, as características principais correspondentes aos dois tipos de estudos mencionados e que reflectem as características gerais dos momentos em que predominaram.

A característica básica que diferencia as duas categorias de estudos é a concepção de mudança social. Os estudos de mobilidade educacional desejam mostrar que, com a industrialização (aspecto económico) e a democratização (aspecto político), foram tornadas iguais as oportunidades educacionais, isto é, a estrutura social tornou-se menos rígida, enfraquecendo os critérios de selecção anteriormente em vigor (como a raça, a classe, religião) e possibilitando a mobilidade social através da educação. Já a visão económica da educação aborda principalmente a mudança do ponto de vista do desenvolvimento económico, onde as alterações técnicas requerem mão-de-obra com um certo nível de qualificação, diferenciando e amplificando as oportunidades profissionais, o que implicaria um papel importante da educação, como instrumento de formação de mão-de-obra.

Podemos concluir dizendo que, apesar das formas diferentes de abordagem, tanto em termos teóricos como metodológicos, a semelhança básica que existe, entre as duas grandes categorias de trabalhos, é que ambos contribuem para uma ideologia vigente, tendo as funções de legitimação, manutenção e reprodução das relações sociais de produção. Os do período 50-60 estão inseridos numa ideologia democratizante, enquanto que os do período posterior são partes integrantes de uma ideologia desenvolvimentista. 


\subsubsection{A Teoria do Capital Humano}

$\mathrm{Na}$ verdade a característica mais distintiva do nosso sistema económico é o crescimento do capital humano.

Schultz (1993: 18)

Foi em 1960 que se formulou a sedutora teoria do capital humano, baseada na observação da reconstrução da República Federal da Alemanha, que pretendia responder à questão fundamental: a quem atribuir a milagrosa recuperação destes países que a guerra tanto devastara, tentando encontrar a causa no famoso factor residual, ou seja, a qualidade da sua mão-de-obra? Nesta perspectiva, o capital humano ocupava um lugar ao lado do outro capital, deduzindo-se daí o seguinte corolário: quanto mais um país invista na educação, mais oportunidades terá de se estimular e instaurar o tão desejado desenvolvimento económico.

A teoria do capital humano partia do princípio de que o ensino era um investimento de primeira importância, comparável às despesas de equipamento, pela vantagem que trazia, simultaneamente, à sociedade e aos indivíduos. Enquanto uma parte importante do crescimento económico não parecia explicar-se pelos progressos técnicos ou pelos investimentos, o factor residual constituído pelo investimento humano e, principalmente, por meio do ensino parecia ser a principal razão para o aumento da riqueza.

É quase um lugar comum entre aqueles que analisam os vínculos entre a educação e o desenvolvimento, educação e rendimento, educação e mobilidade social apoiarem-se em alguns pensamentos da obra de Smith e dos seus discípulos. Por esta razão, se afirma que a teoria do capital humano tem paternidades veneráveis (Hallack, cit. por Teodoro, 1994: 44). Mesmo antes dos clássicos, já os mercantilistas foram os primeiros economistas a referirem a noção de capital humano, embora com uma concepção puramente quantitativa - o que lhes interessa apenas é o número de homens e não a sua qualidade - que ainda se manterá em William Petty (1623 - 1687), considerado em muitos aspectos o percursor da teoria moderna dos recursos humanos.

É, todavia, com Smith, no século XVIII, que a teoria do capital humano começa a ganhar um lugar de destaque no pensamento económico.

Embora seja possível mencionar mais de uma dezena de trabalhos que se referem ao investimento nas pessoas após os dos autores clássicos, é somente a partir do final da década de 1950 que esta ideia se desenvolve 
de forma sistemática, especialmente por trabalhos de pesquisadores americanos e ingleses.

Embora a paternidade moderna de teoria do capital humano seja, inequivocamente, atribuída ao economista e prémio Nobel norte-americano Theodore W. Schultz, os primeiros estudos referenciados com o objectivo de medir a rentabilidade directa do ensino são atribuídos por Khoi ao economista soviético Strumiline que, em 1924, iniciou pesquisas integradas no exame dum projecto de desenvolvimento decenal do sistema escolar, no âmbito do Ministério do Plano, o Gosplan, da URSS, tendo em vista tornar o ensino gratuito e obrigatório (cf. Khoi, 1970, cit. por Teodoro, 1994: 45). Schultz, bem como Denison (cit. por Teodoro, 1994: 46), calcularam o contributo de educação para o crescimento da economia norte-americana na primeira metade do século. Os primeiros ensaios de medida foram baseados tanto numa aproximação contabilística, utilizada por Denison e outros, como na taxa de rendimento do capital humano, método utilizado por Schultz e outros.

Para estes autores, se o crescimento económico era devido inteiramente aos acréscimos em capital físico e em trabalho, então deveria ser possível desagregar a taxa de crescimento do output, entre as suas componentes capital e trabalho. Ao analisar o crescimento económico dos EUA entre 1910 e 1960, Denison constatou a existência de um resíduo que não era possível explicar desse modo, ligando-o então ao efeito da educação sobre a qualidade da força de trabalho e procurando determinar até que ponto estava igualmente ligado a outros factores tais como as melhorias da qualidade do capital físico e as economias de escala.

Desse modo, Denison calculou que, entre 1930 e 1960, quase um quarto $(23 \%)$ da taxa de crescimento do output nos EUA era devido ao acréscimo de educação da força de trabalho (cit. por Teodoro, 1994: 46).

Do ponto de vista macroeconómico, a teoria do capital humano constitui-se num desdobramento e/ou um complemento, como a situa Schultz, da teoria neoclássica do desenvolvimento económico. Foi o conceito de capital humano um meio que, no início da década de 60, indirectamente permitiu a aplicação do modelo neoclássico à educação e ao desenvolvimento dos recursos humanos. Foi o mesmo conceito que forneceu aos economistas neoclássicos razões para defenderem que os governantes tinham que participar nos investimentos educativos e avaliar o rendimento desses investimentos.

Os programas de educação e formação passaram a ser entendidos como meios potencialmente eficazes para melhorar a situação dos países menos desenvolvidos. É neste contexto que, a partir sobretudo do início 
da década de 70, se institucionaliza, pelos menos teoricamente, a prática da planificação da educação, determinada por duas abordagens. Uma orientada pela procura social e assente sobre um certo número de postulados sóciopolíticos (direito do indivíduo à educação, valor desta como meio de promoção social, por exemplo) e sobre novos dados como o crescimento demográfico e o valor sóciocultural atribuído à instrução.

Outra, orientada pelos recursos humanos, que concebe a dimensão económica-produtiva do processo educativo como fornecedora de mão-de-obra qualificada, respondendo às necessidades do aparelho de produção nos diferentes sectores e níveis de emprego.

Mas as divergências de longa data entre as duas correntes dos economistas neoclássicos - liberais e conservadores - romperam, nos anos 80 , o consenso que havia sido estabelecido sobre a ideia de que a educação constitui um investimento social rentável e equitativo. $\mathrm{O}$ desacordo entre ambos ficou a dever-se, fundamentalmente, quanto ao papel que deveria caber ao Estado na educação. Enquanto que os liberais eram adeptos do ensino público nos níveis primário e secundário e de uma forte participação do Estado no nível universitário, os conservadores defendiam um papel mais discreto para o Estado, nomeadamente advogando a redução das despesas públicas com o ensino superior. De comum, contudo, a ambas as correntes encontra-se o facto de reconhecerem que ao Estado deveria caber a função de garantir a igualdade de oportunidades educativas, chave da igualdade de oportunidades no plano económico.

A perspectiva liberal prevaleceu ao longo dos anos 70 e o decénio seguinte foi marcado por uma mudança da ideologia social dos poderes públicos, passando a admitir-se que a melhoria dos serviços públicos exigia a transferência de parte das actividades do Estado nesse sector para o sector privado.

Mas, voltemos agora a Schultz e ao seu conceito de capital humano.

Segundo Schultz (1973: 25), "sempre que a instrução elevar as futuras rendas dos estudantes, teremos um investimento. É um investimento no capital humano, sob a forma de habilidades adquiridas na escola".

Schultz e os seus adeptos pretendem, com o conceito de capital humano, a um tempo, complementar os factores explicativos do desenvolvimento económico na concepção neoclássica, explicar a alta de salários do factor trabalho e explicar, a nível individual, os diferenciais de rendimento. 
A educação, então, é o principal capital humano enquanto é concebida como produtora de capacidade de trabalho, potenciadora do factor trabalho. Neste sentido é um investimento como qualquer outro.

O capital humano revela-se como um conceito vago e de definição complexa: pode englobar, em certos contextos, apenas o nível de escolaridade (nível de educação formal adquirido) ou, em outros contextos, um conjunto mais abrangente de investimentos que influenciam o bem-estar e a produtividade dos indivíduos (tais como investimentos na área de saúde, nutrição, bem como acções de formação profissional adquiridos fora do sistema formal de ensino).

De qualquer forma, a educação formal (ou nível de escolaridade) é usualmente considerada a componente mais importante do capital humano.

Afirma Schultz (1973: 25), a dado passo da sua obra: "Existem numerosos investimentos no capital humano e os números tornam-se elevados. Pode dizer-se, na verdade, que a capacidade produtiva do trabalho é, predominantemente, um meio de produção produzido. Nós "produzimos", assim, a nós mesmos e, neste sentido, os recursos humanos são uma consequência de investimentos entre os quais a instrução é da maior importância".

As taxas de alfabetização são, actualmente, um indicador estatístico que se encontra amplamente difundido, levantando, contudo, alguma insatisfação, porque medem apenas uma componente do capital humano corrente, não reflectindo as qualificações obtidas para lá dos níveis elementares de escolaridade. A alfabetização é apenas a primeira fase no processo de formação do capital humano, existindo outros aspectos deste que são tão ou mais importantes para a melhoria da produtividade dos indivíduos e, consequentemente, das empresas e das nações.

Um outro indicador, utilizado em inúmeros estudos, para quantificar o conceito de capital humano é a taxa de escolarização num determinado grau de ensino ${ }^{4}$, dada a sua ampla disponibilidade para muitos países.

De qualquer forma, alguns autores apontam deficiências a estas taxas, bem como às da alfabetização.

Argumentam que as taxas reflectem fluxos correntes de educação e apenas a acumulação destes fluxos constitui um stock de capital humano que estará disponível no futuro. Como o processo de educação envolve vários anos, o desfasamento temporal entre fluxos e stocks é, em geral, muito elevado. Para além disso, esses autores salientam as limitações das taxas de matrícula quanto à sua relação com as taxas de crescimento económico. Esta insatisfação levou vários autores a construírem outras 
medidas mais elaboradas para estimar o stock de capital humano. Alguns economistas associados à área do desenvolvimento económico procuraram melhorar a utilização das taxas de matrícula como indicador de capital humano, tentando quantificar este último de uma forma mais directa através dos anos médios de escolaridade da população como um todo, ou de subgrupos da mesma. Levam em linha de conta os ratios da matrícula passados e, portanto, a acumulação dos esforços de investimento na educação, em vez dos fluxos contemporâneos desta última $^{5}$

Noutra parte da sua obra "O Valor Económico da Educação", Schultz (1973: 64) interroga-se: Porquê insistir no conceito de capital humano? Responde afirmando que para esclarecer esta questão é essencial que o conceito de capital humano tenha uma definição. Assim, prossegue Schultz: "Um conceito de capital restrito a estruturas, equipamento de produção e património, é extremamente limitado para estudar tanto o crescimento económico mensurável (rendimento nacional) como, o que é mais importante, todas as conquistas, no bem-estar, geradas pelo progresso económico (o que inclui, também, os prazeres em que as pessoas encontram maior lazer, na crescente acumulação de bens duráveis, em possuir melhor saúde e mais educação - tudo isto omitido na nossa actual estimativa de rendimento nacional)".

Kuznets (cit. por Schultz, 1973: 64) vê o problema claramente, numa passagem do seu estudo, quando observa que, para o "estudo do crescimento económico, abrangendo períodos longos, e entre comunidades tão diferentes, o conceito de capital e de formação de capital deveria ser ampliado, de forma a incluir investimento para saúde, educação e investimentos em seres humanos. Sob este ponto de vista, o conceito de formação de capital, aqui observado, é excessivamente limitado".

Mais adiante Kuznets (ibid.) acrescenta o seguinte raciocínio: "Os bens de produção - estruturas, equipamentos e patrimónios - em especial stock de capital, tem declinado em relação ao rendimento. Enquanto isso, no entanto, o stock de capital humano tem aumentado em relação ao rendimento. Terão sido as decisões básicas, que respondem por estes oscilações, provocadas por diferenças das taxas de rendimento? A solução contudo é: se a proporção da totalidade do capital, em relação ao rendimento, permanece essencialmente constante, então o inexplicado crescimento económico é provocado por formas de capital ainda não identificadas e dimensionadas, constando, principalmente, de capital humano". Entre outros autores que adoptaram o conceito de capital 
humano já referimos anteriormente Denison (1962), que usou o conceito de função de produção com a finalidade de identificar o impacto dos diferentes factores de produção para o aumento da produção nacional.

Para terminar este ponto, ainda nos referiremos, finalmente, ao trabalho de dois outros autores efectuado em 1960. Trata-se do trabalho de Harbison e Myers (cit. por Frigotto, 1989: 41-42) sobre comparações internacionais, talvez o mais completo e que tem gerado maior impacto e alimentado o discurso - especialmente nos governos dos países subdesenvolvidos - sobre a eficácia da educação como instrumento de desenvolvimento económico e a distribuição do rendimento e igualdade social. Estes autores tomaram um índice de desenvolvimento de recursos humanos formado na base do fluxo de pessoas matriculadas nas escolas secundárias, com idade entre 15 e 18 anos, e o fluxo de pessoas entre 20 e 24 anos que estavam no ensino superior, de 75 países, e correlacionaram-no com o PNB per capita de cada país. A correlação encontrada foi de $\mathrm{r}^{2}=0,789$. Inferiu-se daí a relevância da educação para $\mathrm{o}$ desenvolvimento económico.

Esse trabalho, embora mantenha ainda hoje, pelo menos entre nós, um forte apelo ideológico, foi muito criticado internamente pelos adeptos da teoria do capital humano.

Entre outras críticas sobressaem: as ponderações que os autores fazem na construção do seu índice de desenvolvimento de recursos humanos, o facto de compararem um fluxo (pessoas no processo educativo) com um stock (PNB per capita) de pessoas do mercado de trabalho e o facto do modelo estatístico de correlação não permitir inferências causais, mas apenas de vínculo.

Não só este trabalho como todos os outros realizados pelos adeptos da teoria do capital humano foram objecto de inúmeras críticas, como iremos ver no ponto seguinte do nosso estudo.

\subsubsection{Críticas à teoria do Capital Humano}

As críticas à teoria do capital humano são numerosas. Umas feitas pelos próprios economistas em função da crise económica dos anos setenta, pondo em causa a apregoada relação entre o investimento na educação e o crescimento económico.

Outras críticas tiveram a sua origem na Sociologia, pondo em causa os próprios fundamentos teóricos do conceito de capital humano. 
No campo da teoria económica, o decénio de 1980 foi testemunha de uma duríssima crítica àqueles autores que afirmaram e defenderam a relação entre a educação e o desenvolvimento. Na verdade, vinte anos de crescimento não conseguiram acabar com o fosso da desigualdade económica entre o Norte e o Sul nem atenuar as desigualdades internas dos países em desenvolvimento. Mas, na realidade, o que os anos 80 puseram em relevo foi a extraordinária complexidade das relações entre a educação e o desenvolvimento. Mais ainda: hoje sabemos que a relação entre ambos os conceitos do binómio nunca é abstracta, mas está condicionada por múltiplos elementos circundantes.

A complexidade do binómio refere-se tanto aos países desenvolvidos como àqueles que tentam superar o atraso económico em que se encontram. A complexidade desta dicotomia não significa que a relação não exista, mas que se encontra obscurecida por muitos outros factores, exógenos e endógenos, tais como a riqueza relativa do país, a sua estrutura social, a qualificação da mão-de-obra, o crescimento demográfico, o próprio sistema educativo, etc.

Tudo isto sugere que as relações entre a educação e o desenvolvimento não possam ser contempladas com simplicidade. Alguns economistas concordam com Schultz quando afirmam que a educação é razoavelmente mais importante em ambientes modernos do que em tradicionais.

Ainda que tenham sido muitos os estudos empíricos que se aplicam a esta questão, não se tem podido verificar nem medir com exactidão a importância de educação para o desenvolvimento económico. Mas uma coisa é certa: os países com elevado nível de rendimento estão dotados de sistemas educativos modernos.

Isso não quer dizer que exista uma relação mecânica, de causa-efeito, entre a educação e o desenvolvimento, nem que só o investimento na educação conduza ao desenvolvimento económico.

Do campo da sociologia emergiram numerosas críticas à teoria do capital humano. Assim, por exemplo, Petitat (cit. por Teodoro, 1994: 47) considera:

"A linguagem utilizada pelos defensores do capital humano dá a ilusão que o assalariado é um capitalista que investe nele próprio. Ora, a sua posição é antes de um consumidor podendo fazer um certo cálculo económico: na sua decisão de prosseguir ou de abandonar os seus estudos, o aluno pode fazer intervir, entre outros elementos, uma estimativa das vantagens em salários para um ou vários anos de estudos suplementares. O aluno não investe: adquire mercadorias (saber-fazer e 
conhecimentos) que conta poder revender mais tarde a alguém que delas necessite como capital; faz uma aposta sobre o mercado de trabalho futuro".

Page (ibid. 48), embora não pondo em causa a contribuição de educação para o desenvolvimento, refuta a linearidade da afirmação de que existe uma correlação entre $o$ investimento na educação e $o$ crescimento económico. $\mathrm{O}$ autor afirma:

"A educação não é automaticamente factor de mudança e de progresso [...] De toda a maneira, a educação não pode senão criar um potencial humano susceptível pela sua formação de jogar um papel positivo no desenvolvimento".

Parker (ibid.), após várias investigações sobre o assunto, conclui:

"A sobreeducação de massa pode também ser uma causa de catástrofe, se não é prestada suficiente atenção ao conteúdo (da formação), mas igualmente às aspirações explícitas e implícitas dos estudantes e das suas famílias, aspirações que podem ser em certos casos, prioritariamente, de melhorar uma situação material".

As críticas internas (aquelas que partem dos próprios adeptos da teoria do capital humano) sobre o modelo apresentado por Denison (1962) são inúmeras. Por exemplo, Abramovitz (cit. por Frigotto, 1989: 43) denomina o "resíduo" atribuído à educação, "índice da nossa ignorância", querendo enfatizar a debilidade desse tipo de medida.

As tentativas de medir, em termos macro, a contribuição da educação para o crescimento económico têm esbarrado, do ponto de vista da investigação, nas mais diversas críticas internas à teoria. Essas críticas prendem-se fundamentalmente com a debilidade das medidas que tentam apreender o impacto da educação sobre o crescimento.

Os métodos propostos pelos defensores da teoria do capital humano, para tentar quantificar a contribuição da educação para o desenvolvimento, demonstraram várias dificuldades, não tendo chegado nenhum deles a resultados convincentes.

Por outro lado, alguns autores rejeitaram a consideração prática do homem como capital humano. É o caso de Shaffer (cit. por Blaug, 1972: 43-48) o qual afirma:

"O investimento no homem é essencialmente diferente do investimento em capital humano [...] (não é um investimento com efeitos demonstráveis sobre a produção futura e a satisfação directa das necessidades) [...] rara vez é um investimento racional".

Por outro lado, diversos e interessantes estudos ressaltam a importância dos factores biológicos e sociais na educação do indivíduo, 
relegando para segundo plano o papel da escola e da educação institucional.

A deslocação da análise macro para a análise microeconómica da teoria do capital humano veio ressuscitar os conceitos da teoria neoclássica do marginalismo. O suposto básico microeconómico é de que o indivíduo, do ponto de vista da educação, é uma combinação do trabalho físico e educação. Supõe-se, por outro lado, que o indivíduo é produtor das suas próprias capacidades de produção, chamando-se, então, investimento humano ao fluxo de despesas que ele deve efectuar ou que o Estado efectua por ele, em educação, para aumentar a sua produtividade. A um acréscimo marginal de escolaridade, corresponderia um acréscimo marginal de produtividade. O rendimento é considerado como função da produtividade, donde, a uma dada produtividade marginal, corresponde um rendimento marginal.

$\mathrm{Na}$ base deste raciocínio (silogístico) infere-se que a educação é um eficiente instrumento de distribuição de rendimento e igualdade social.

A deslocação da análise macro para a micro não muda em nada as hipóteses da teoria. Ao contrário, trata-se de uma medida técnica para livrar a investigação das críticas de carácter pouco consistente da construção dos índices que permitem calcular a rentabilidade da educação.

Desenvolveu-se dentro da óptica microeconómica uma grande quantidade de trabalhos sobre análises de custo-beneficio, taxas de retorno e mesmo técnicas de provisão de mão-de-obra (manpower approach) cujo objectivo, no primeiro caso, é tentar medir, a nível micro, o efeito de diferentes tipos e níveis de escolarização, em termos de retorno económico e, no segundo, buscar ajustar requisitos educacionais a necessidades do mercado de trabalho nos diferentes sectores de economia, tanto a nível macro, como micro.

Embora as análises microeconómicas aparentemente permitam uma maior confiabilidade na construção dos indicadores utilizados, a redução das variáveis que explicam o rendimento como a idade e a experiência, por um lado, a dificuldade de se construir os perfis idade-rendimento e as hipóteses que supõem (mercado de concorrência perfeita), por outro, fazem que essas análises se tornem cada vez menos frequentes e menos aceites pelos próprios adeptos de teoria do capital humano.

Para terminar, pretendemos ainda expor um outro tipo de crítica interna à teoria do capital humano, desenvolvida em pesquisas mais recentes. Refere-se ao privilégio que essa teoria tem dado aos 
componentes cognitivos na explicação do sucesso profissional, rentabilidade, etc.

Um primeiro conjunto de trabalhos deriva de uma inspiração típica da sociologia funcionalista, em cuja fonte encontramos os trabalhos de Parsons (1961). Robert Dreeben (cit. por Frigotto, 1989: 47) desenvolve um trabalho sistemático defendendo a tese de que, dadas as características estruturais próprias da escola se aprende nela um conjunto de normas que vão definindo atitudes de independência, realização, universalismo, especificidade, funcionais às organizações da sociedade industrial.

Outro conjunto de trabalhos, com apelo às análises marxistas, desenvolveu-se nos EUA valendo a esses autores a identificação, nos meios académicos, de os "Radicais Americanos". Destacam-se, entre os mais citados na literatura que aborda esta questão, os trabalhos de Bowles, Gintis, Edwards, Levi, Carnoy, entre outros. Bowles (cit. por Frigotto, 1989: 47), contestando a possibilidade da escola promover a igualdade, destaca que esta fornece força de trabalho disciplinada e habilitada, ao mesmo tempo que fornece os mecanismos de controlo social para a estabilidade do sistema social capitalista.

Gintis (Id., Ibid.), ao refutar o vínculo existente entre a escolaridade e o salário, dá ênfase à importância da formação de atitudes requeridas pelo mercado de trabalho.

"Na realidade a escola contribui para formar uma força de trabalho socialmente requerida, inculcando uma mentalidade burocrática aos estudantes" (Gintis, 1971).

A escolarização, de acordo com Gintis (cit. por Frigotto, 1989: 47), "que influi de maneira considerável sobre a personalidade dos indivíduos, é reduzida progressivamente ao seu papel funcional: ela favorece as condições psicologicamente requeridas para formar a força de trabalho alienada que é desejada".

Edwards, de igual forma, dá ênfase aos traços desenvolvidos na escola e à sua funcionalidade na hierarquia ocupacional da empresa moderna. (Edwards, cit. por Frigotto, 1989: 48). Em suma: para estes autores, a educação escolar é um aspecto da reprodução da divisão capitalista do trabalho.

Quanto a estas análises, ainda que apontem para alguns aspectos significativos, apenas se desenvolvem dentro de uma linguagem marxista, afastando-se, contudo, do método e da teoria marxista.

Trata-se de análises que, sob um aspecto, apenas deslocam o vínculo da relação economia-educação, educação-trabalho, dos traços cognitivos para o campo afectivo, valorativo, comportamental, não transpondo o 
quadro das análises anteriores, de carácter funcional. Sarup (1980: 155), ao analisar os trabalhos de Bowles e Gintis, salienta que "embora tenham uma posição marxista, a sua visão da sociedade é funcional estruturalista derivada de Durkheim e Parsons".

Afirma o autor (Ibid. 158-160) que "o tipo de análise conduzido por Bowles e Gintis não vislumbra que as relações capitalistas de produção não determinam, necessariamente, um total domínio sobre o homem e que este não é deterministicamente passivo". O carácter reducionista da análise não permite aos autores perceber que a reprodução, via escola, família, etc., que efectivamente ocorre, não se dá de forma tão linear, mas por mediações de diferentes naturezas. Da mesma forma, não percebem que o trabalho escolar pode, igualmente por mediação, desenvolver um tipo de relação que favorece a óptica dos dominados. O problema básico da linha de análise dos citados autores reside na não apreensão das categorias fundamentais da análise do método histórico dialéctico.

Max-Neef (1994: 107) é peremptório ao afirmar que a Teoria do Capital Humano, para além de poder ser "contestada no plano ético, contém um sofisma ideológico mercê ao qual os trabalhadores também aparecem, de certa forma, como capitalistas. A teoria do capital humano reduz o trabalho humano à condição de capital acumulável mediante investimentos em educação e formação".

\subsubsection{Anos 1980: a renovação da Teoria do Capital Humano}

Apesar das críticas, a teoria do capital humano teve uma larga difusão, para a qual muito contribuíram instituições inter-governamentais como a OCDE, o Banco Mundial ou o FMI. Algumas dessas instituições continuaram a fomentar investigações em busca de novas provas da existência de laços, entre diversos aspectos do desenvolvimento dos recursos humanos e o crescimento económico (exemplo: estudos de Hicks, 1980). O livro publicado em 1988 pelo Banco Mundial, L'Éducation pour le Développment. Une analyse des choix d'investissement, constitui um documento fundamental para a compreensão das modernas aplicações da teoria do capital humano.

Foi devido a esta teoria, $t$ ornada paradigma dominante na economia da educação, nos anos 60, que se verificou um forte incremento das despesas públicas com a educação. Contudo, em virtude da crise dos anos 70, a decepção face aos resultados de algumas reformas educativas 
fizeram, de acordo com a expressão utilizada por Becker (1976), com que o ensino deixasse de estar na moda (Teodoro, 1994: 42).

Verifica-se, todavia, nos anos 80 , um regresso e renovação da teoria do capital humano. É esse já o sentido da generalidade dos artigos publicados no dossier preparado em 1988 pela revista Éducation Permanente sobre o Investimento na Formação.

A irrupção da economia no campo dos bens imateriais, o acento colocado sobre o conhecimento, a introdução de novos conceitos como o da competitividade, permitem considerar que, sucedendo ao período de desencanto dos anos 70, estamos perante a emergência de um novo período, em que aos sistemas que produzem conhecimento (educação e investigação) se atribui um papel central nos processos de desenvolvimento das sociedades.

O novo vocacionalismo na expressão de Stoer et al. (1990: 11-53) que caracteriza a política educativa dos anos 80 , bem como algumas medidas de política educativa tomadas, nos anos 90 , pelos poderes públicos, não são outra coisa senão o retomar da teoria do capital humano, agora incidindo, em particular, no conceito de investimento privado do processo de formação (a criação de um forte sector privado de ensino, por exemplo, insere-se nesta lógica de redução e de crítica ao chamado Estado Providência).

As medidas concretas propostas no Livro Branco (Livro Branco sobre Crescimento, Competitividade, Emprego - os desafios e as pistas para entrar no século XXI"), publicado pela Comissão das Comunidades Europeias em 1993 e inspirado, segundo os seus autores, “[...] nas contribuições transmitidas pelos Estados-Membros e baseado [...] também nos debates em curso nos nossos países entre o Estado e os parceiros sociais, debates esses que têm sido frequentemente balizados por conflitos", relativamente à "adaptação dos sistemas de educação e formação profissional", manifestam uma clara sintonia com aquelas que se podem considerar algumas traves-mestras do movimento referido, nomeadamente:

1 - O reforço da vertente profissionalizante dos sistemas de ensino, ao nível secundário, através da criação de vias paralelas, ditas alternativas, aos percursos de formação geral (Livro Branco, 1993: 26).

2 - A definição de novos conteúdos para a educação (em sintonia com "as novas exigências") referindo, por vezes, a generalização dos conhecimentos de base para lidar com as novas tecnologias, 
particularmente, as da informação (Livro Branco, 1993: 17-26126).

3 - (O apelo à) constituição e legitimação de um novo protagonismo e participação das empresas quer na definição das políticas educativas, a nível central, quer da sua implementação aos níveis regional e local (Livro Branco, 1993: 124).

Em conclusão, no que à educação escolar diz respeito, o Livro Branco sobre "Crescimento, Competitividade, Emprego" reafirma, nos anos 90, a ortodoxia qualificacionista/adequacionista" (com origem nos anos 50) para fundamentar o que, na década de 80, foi identificado como um "novo vocacionalismo" (Stoer et al., 1990).

Altos responsáveis do Banco Mundial, tais como Burnett, Marble e Patrinos, reconhecem num artigo publicado na Revista Finanças $e$ Desenvolvimento (1995: 40-42) que a educação é um investimento económico seguro. Nesse artigo esses economistas afirmam nomeadamente:

"Nos últimos anos, generalizou-se o reconhecimento da importância de se investir em capital humano, o que é visto como parte essencial dos esforços para aumentar o rendimento e atingir o crescimento económico sustentado. O ritmo de mudança tecnológica, as reformas económicas e o rápido aumento do conhecimento acarretarem, para os indivíduos, mudanças mais frequentes na área do emprego. Isto criou duas prioridades fundamentais para a educação: atender à procura crescente das economias por trabalhadores adaptáveis e capazes de adquirir prontamente novas habilidades e sustentar a expansão contínua do conhecimento".

Esses autores chegam mesmo a afirmar que os investimentos maciços, tanto na educação primária como na primeira fase da secundária complementados por modelos de crescimento que canalizam a mão-de-obra para usos produtivos -, foram um dos elementos fundamentais do "milagre" do desenvolvimento do Leste Asiático e que outros países, como o México e a Índia, tendo feito essa constatação mais recentemente, deram início a uma profunda ampliação e reforma dos seus sistemas de educação básica.

Também a educação actualmente é considerada, por muitos autores e por várias organizações internacionais, como o motor da modernização, sendo o factor humano encarado como um factor de competitividade tão importante como o factor tecnológico.

Entendendo modernização como um processo contínuo, "uma mudança de atitudes, uma renovação de mentalidades, um sistema 
complexo e uma intervenção contínua sobre uma realidade complicada" (Barata e Ambrósio, 1988: 113-114), a educação ocupa um lugar central, que resulta, em primeiro lugar, dessa nova situação emergente no nosso século de uma interdependência entre ciência e técnica.

Também, e na expressão de Rodrigues (1991: 124-125), “a emergência de um novo paradigma técnico-económico traz igualmente para primeiro plano o papel de educação na modernização social".

Kovacs (cit. por Teodoro, 1994: 53) afirma que o modelo que ela designa por burocrático (taylorista-fordista), e que prevaleceu até aos anos 60 , se esgotou e se tornou ineficaz, face às novas exigências do mercado e ao processo de mundialização da economia e da tecnologia. Para o autor, dada a emergência de novos sistemas produtivos, a empresa e o trabalho têm de ser encarados de forma diferente, não podendo ser vistos apenas como espaços de produção de bens e serviços, mas também como espaços de produção social e cultural, espaços de expressão de subjectividade, de identidade e de integração para indivíduos e grupos. $\mathrm{Na}$ nova lógica de empresa que está a emergir, o factor humano surge como um factor de competitividade tão importante como o factor tecnológico.

Segundo o Relatório Mundial sobre o Desenvolvimento Humano de 1990, se as qualificações humanas constituem agora o aspecto mais importante das actividades modernas da banca, da finança, de gestão de negócios e da administração pública, então a emergência de uma nova economia mundial dos serviços desloca a vantagem comparativa entre países dos recursos naturais para as pessoas. 


\subsubsection{Anos 1990: Educação e Desenvolvimento - que relação?}

O principal motor do crescimento económico é a acumulação de Capital Humano... e a principal fonte das diferenças nos padrões de vida entre as nações são as diferenças em capital humano.

(Lucas, 1993: 270)

Investir em educação é para os anos 90 o que a nacionalização foi para os anos 40 e a privatização para os anos 80 - a panaceia universal do momento.

(The Economist, 1992: 17)

Durante os anos 90, podemos identificar duas perspectivas diferentes no que se refere à relação entre a educação e o desenvolvimento. A primeira, defendida pelos novos modelos de crescimento e baseada em estudos empíricos, contribuiu para um renovado interesse no capital humano. A segunda, mais céptica, é assumida por outros autores, questionando, novamente, duma forma pessimista, a relação entre a educação e o desenvolvimento.

Quanto à primeira, alguns estudos como, por exemplo os de Barro (1991) e de Benhabib e Spiegel (1994) concluem que o Capital Humano se encontra correlacionado com o crescimento económico ${ }^{6}$. No primeiro trabalho (Barro, 1991, cit. por Teixeira, 1999: 17) chega-se a esta conclusão após um estudo abrangendo 98 países entre 1960 e 1985 . O capital humano passa a constituir, nesta perspectiva, mais um factor de produção, para além dos tradicionais factores de produção: o capital físico, o trabalho (mão-de-obra não qualificada) e o progresso tecnológico.

O estudo de Benhabib e Spiegel (ibid. 18), baseado numa amostra cross-country de 78 países entre 1960 e 1985, vai mais longe, demonstrando que o stock de capital humano ${ }^{7}$ só se torna significativamente correlacionado com a taxa de crescimento económico quando associado à capacidade de inovação de economia. Nesta abordagem, portanto, o stock de capital humano não é um simples factor de produção mas antes um factor crítico para a sustentação da capacidade de inovação de uma economia ${ }^{8}$. 
Esta está implicitamente relacionada com o esforço dedicado à Investigação e Desenvolvimento (I \& D).

Outro estudo, de natureza diferente, levado a cabo por Rosángela Di Paola, Miriam Bergés e Elsa Rodriguez, em 1993, na cidade de Mar del Plata, na Argentina, teve como objectivo medir os efeitos internos do capital humano ${ }^{9}$. O trabalho propôs-se analisar os elementos determinantes do rendimento dos chefes de família da cidade de Mar del Plata, utilizando a teoria do capital humano que centra a atenção no poder explicativo das variáveis educação e experiência. O modelo econométrico aplicado baseou-se na função estatística do rendimento desenvolvida por Mincer, em que os anos de escolaridade, a experiência laboral e variáveis qualitativas, como a raça e o género, cumprem um papel importante na determinação do rendimento. Concluiu-se que as variáveis que melhor explicam o nível de rendimento são o nível máximo de educação alcançado e os anos de experiência laboral adquiridos. Como consequência da depreciação do capital humano ao aumentar a idade do indivíduo, os seus rendimentos, uma vez alcançado o máximo, tendem a diminuir.

Não sendo nossa intenção prolongar demasiado a exposição destas investigações, limitar-nos-emos à divulgação dos estudos anteriores, embora muitos outros pudessem ser apresentados ${ }^{10}$.

Ainda dentro da primeira perspectiva, os novos modelos de crescimento endógeno (Romer, 1986; Lucas, 1988), ao ultrapassarem as limitações do progresso tecnológico exógeno do modelo neoclássico tradicional, colocam a acumulação do capital humano como fonte determinante do crescimento económico ${ }^{11}$.

Para grande parte dos novos modelos neoclássicos de crescimento (Grossman e Helpman, 1991; Barro e Sala - I -Martin, 1995; Aghion e Howitt, 1998, por exemplo), o factor determinante do crescimento económico é a inovação tecnológica (ou, de forma equivalente, o progresso tecnológico endógeno). Esta actividade inovadora, gerada no interior da economia, é ela própria influenciada pela dotação da economia em capital humano, já que os avanços tecnológicos são, regra geral, fruto do esforço de indivíduos que detêm qualificações especiais (cientistas, engenheiros, etc.), sendo estes últimos uma componente do capital humano.

Assim, a emergência dos modelos de crescimento endógeno (Lucas, 1988), associados às modernas teorias do crescimento económico traz para a ribalta dois importantes papéis do capital humano. Por um lado, o capital humano é um input produtivo (tal como o capital físico e o 
trabalho) e o crescimento económico é função da acumulação desse input. Por outro lado verifica-se um impacto positivo do capital humano na capacidade de inovar. A educação, enquanto componente principal do capital humano, aparece aqui, assim, estreitamente interligada ao processo de inovação, já que, em geral, uma população com um nível de escolaridade elevado, para além de aumentar a probabilidade de ocorrência de inovações, tende a absorver com relativa facilidade as inovações/mutações tecnológicas (Benhabid e Spiegel, 1994, cit. por Teixeira, 1999: 29).

Aceitando como válidos os pressupostos teóricos de abordagem dos autores anteriores (importância da interacção do capital humano ao nível de capacidade de inovação), poder-se-á inferir que: a) o crescimento da produtividade, ou da taxa de inovação, tende a aumentar com o nível de escolaridade; b) a produtividade marginal do capital humano (isto é, os acréscimos relativos de rendimento/produto, obtidos por cada acréscimo adicional no nível de escolaridade) é uma função crescente da taxa de progresso tecnológico.

Outras funções do capital humano relacionam-se com as questões do desemprego e desigualdade nos níveis de rendimento. Assim, alguns autores como, por exemplo, Zon e Muyskan (1996, cit. por Teixeira, 1999: 30), referem que a acumulação de capital humano tende a ser uma arma contra o desemprego, na medida em que este último tende a ser mais comum e permanente nos grupos de indivíduos com níveis de formação mais baixos. Nesta perspectiva, uma política de educação generalista (cujo objectivo consiste no aumento do nível médio do stock de capital humano de economia), ao permitir um incremento na mobilidade do factor trabalho, é susceptível de reduzir a desigualdade nos rendimentos (Aghion e Howitt, 1998, ibid.).

Nos anos 90 registaram-se preocupações generalizadas em todos os países a nível mundial, quanto à importância da educação. Todas estas preocupações foram reflexo do enorme impacto da problemática suscitada pelas questões do capital humano, a qual originou uma generalização, a nível europeu, de medidas de política conducentes a alterações nos sistemas educativos. Verificam-se, então, em muitos países, reformas dos sistemas de ensino, que traduzem duas assunções básicas por parte das autoridades públicas.

Primeiro, que as mudanças económicas e tecnológicas que têm ocorrido nestas duas últimas décadas exigem novos e mais elevados níveis de capital humano. Segundo, que o governo tem capacidade para alterar o sistema de educação e de formação profissional, de maneira a 
melhorar os respectivos resultados e assim a aumentar a performance económica da nação.

A segunda perspectiva, de que falámos anteriormente, relativamente à relação entre a educação e o desenvolvimento, evidencia uma visão mais crítica e pessimista do papel do capital humano. No nosso país, por exemplo, Azevedo (1994a: 141) afirma que a relação educação-desenvolvimento é complexa, está repleta de perplexidades, de tensões e paradoxos. Para o autor "assistimos a uma crise da ideologia desenvolvimentista que tem permanecido, nas últimas décadas, acoplada aos investimentos gerais nos sistemas educativos. A educação escolar apresenta algumas limitações e encontra resistências sérias ao exercício do papel social relevante". Azevedo apresenta alguns casos concretos de tal situação:

- "a transição de uma escola de elites para uma escola de massas (movimento quase comum a todos os povos nesta segunda metade do séc. XX) transportou consigo uma certa degradação da qualidade do serviço público de educação;

- a procura social e individual da educação cresceu enormemente, mas a escola tem marginalizado uma parte, mais ou menos substancial da população do acesso aos benefícios educacionais, quer dizer à igualdade de acesso não tem correspondido a igualdade de sucesso (OCDE, 1983; Souto, 1981, Campos, 1985, cit. por Azevedo, 1994a: 142);

- a homogeneização social, a que a escolarização tem conduzido (típica dos requisitos da industrialização galopante das sociedades e das economias), tem provocado o desenraizamento cultural e social das populações (todos têm de adquirir os mesmos saberes sobre as mesmas coisas, tendo em vista a sua melhor inserção social e participação no processo produtivo);

- um dos maiores espinhos que se cravou na ideologia desenvolvimentista que se associou à educação escolar foi o excesso de crença nos diplomas e na sua especialização. Constatou-se, em muitos casos, a sua inutilidade perante as situações de desemprego de diplomados, em número crescente, por exemplo na Europa;

- cresce, por outro lado, a insatisfação juvenil e a sensação de que a irrelevância dos saberes escolares é superior à sua adequação, pertinência e utilidade pessoal e profissional;

- as perspectivas, acalentadas durante muitos anos, de que os investimentos em educação tinham um impacto muito significativo 
no crescimento económico têm sido muito difíceis de provar. Os modelos construídos para o tentar evidenciar são muito criticados e provam muito pouco, tanto em termos de impacto positivo como negativo. Contudo, não há dúvida da correlação positiva entre a instrução básica e um certo potencial de desenvolvimento social, cultural e económico;

- as escolas são, muitas vezes, instituições estranhas às comunidades locais - os sistemas nacionais de educação e de formação são normalmente planificados centralmente, uniformemente concebidos, administrativamente fechados sobre si próprios".

É neste contexto que Garcia Garrido (cit. por Azevedo, 1994a: 144) afirma: "a amarga realidade é que os nossos sistemas educativos, depois de alguns anos de euforia num aparente impulso em direcção ao progresso, conheceram o fracasso, incluindo a não consecução dos seus objectivos económicos".

Em suma, a relação entre a educação e desenvolvimento não é linear, é crítica, apresenta-se com elevado grau de complexidade. Complexidade à qual estamos condenados, segundo Perrenoud (ibid., 156).

Azevedo ( $i b i d$.) defende que a "crise subjacente a esta relação entre educação e desenvolvimento não é essencialmente escolar e formativa, mas do próprio modelo de sociedade e de desenvolvimento: é o falhanço de certas vias de crescimento económico, é a falência de certos paradigmas de decisão política e da acção administrativa, é o impasse a que conduziu uma certa organização social e um certo papel do Estado".

Esta crise da relação entre a educação e o desenvolvimento, segundo alguns autores, arrasta-se até à actualidade, facto que é reafirmado nomeadamente por Azevedo, que já citámos antes. Este autor continua a afirmar que o actual modelo está realmente esgotado - a persistência de elevado desemprego juvenil na Europa e a sensação de crise generalizada mostram como o caminho escolhido não produziu os resultados desejados, requerendo uma escola organizada de forma diferente (Azevedo, 1999a: 2).

"A escola que recebe todos não tem propostas educativas para todos, mas apenas para uma parte, ainda que maioritária [...]. A Escola que recebe todos ainda não é escola para todos. Mudou o acesso, mudam muito lentamente as condições para o sucesso" (Azevedo, 1994b: 124).

Para o autor, as reformas europeias do sistema educativo (ele mesmo protagonista da reforma portuguesa) aconteceram simultaneamente (entre início e meados dos anos 90) e todas tiveram a mesma finalidade: despecializar ao máximo o ensino secundário, unificá-lo e concentrá-lo na 
oferta de uma formação genérica de base. As reformas andavam todas atrás dos discursos económicos. Estava-se perante um mandato da economia a braços com altas taxas de desemprego juvenil e uma retracção do mercado do primeiro emprego que se tornava imperioso resolver. $\mathrm{O}$ discurso económico politiza-se e o discurso político dominante torna-se quase exclusivamente económico e de cariz produtivista: "é necessário preparar as novas gerações para a adaptação a um mercado de emprego e a uma economia impregnada de grande incerteza, caracterizada pela inovação técnica, a flexibilidade laboral e a globalização económica. Ao sistema de ensino pede-se que seja capaz de preparar os futuros trabalhadores para uma maior mobilidade profissional, para uma maior rotatividade entre os postos de trabalho e para as alternâncias empregodesemprego" (Azevedo, 1999a: 3).

Apesar das reformas do ensino, parece continuar a verificar-se, afinal, um desajustamento crónico entre educação-formação e economia-emprego, ou seja, um enorme desencontro entre as necessidades do mercado de emprego e a procura do nível de formação.

Portanto, a relação entre a educação e a economia, que muitas vezes é difundida como uma coisa linear e muito estreita, na realidade não acontece. Verifica-se um desajustamento crónico e evidente entre a produção do sistema educativo e o funcionamento e as necessidades de economia.

No âmbito externo, nos anos 90, alguns autores adoptam posições críticas, pondo em causa a Teoria do Capital Humano, no que se refere tanto aos seus efeitos internos como externos.

Assim, os argumentos sobre a contabilidade do crescimento económico, tal como os apresentados por Becker em 1994 (cit. por Fitzsimons, 1997: 1-5), mostram, no mínimo, que a educação contribui para diferenças nos rendimentos entre as pessoas, mas só em determinadas circunstâncias. Este cepticismo vem de Blaug (ibid.) que argumenta que se deve dizer que os modelos examinados na literatura, sobre o cálculo do crescimento, falham completamente na explicação do mecanismo pelo qual este efeito é produzido. A discórdia sobre se o crescimento económico emana da educação não é pacífica, porque enquanto se pode admitir que a educação contribui para o crescimento, isso mesmo o faz outras actividades. Blaug (ibid.) diz que aquilo que deve ser esclarecido não é se a educação contribui para o crescimento, mas que mais educação contribui para mais crescimento, retirando outros factores como mais saúde, mais habitação, mais estradas, etc. 
O fundamental é que o cálculo do crescimento ignora os custos dos recursos já investidos no sistema educativo e, portanto, não nos diz nada sobre os retornos líquidos dos gastos na educação. Na mesma linha, Hyde (1999) afirma peremptoriamente que "a influência das formas de pensar dos defensores da teoria do capital humano tem sido inteiramente negativa. A sua base económica, a qual tem falhado totalmente, é defender que os retornos económicos são função dos anos de escolaridade ou de formação".

Esta tese foi um insucesso, pela simples razão de que não há uma relação simples entre escolaridade e rendimentos. $\mathrm{O}$ valor dum ano adicional de escolaridade depende de factores exógenos relativos ao indivíduo e às oportunidades económicas que se lhe abrem. A teoria do capital humano explica a frequência da escola como um investimento que será remunerado com rendimentos futuros, mas o problema (o qual é sempre identificado pelos teóricos do capital humano e prontamente ignorado), é que os anos adicionais de escolaridade contribuem com diferentes níveis de rendimentos, dependendo do ano de escolaridade frequentado, de quem é o beneficiário e de que tipo de trabalho é o desse mesmo beneficiário.

Bouchard (1999: 2-7) desmonta aquilo a que ele designa por alguns mitos sobre o capital humano. Um desses mitos é o de que o capital humano é um investimento para o futuro. Um dos princípios básicos da teoria do capital humano de Schultz é que a formação é uma resposta a futuras necessidades e que representa uma salvaguarda contra a sempre presente ameaça da obsolescência económica. Diz o autor: "de acordo com esta visão, os programas de formação de hoje devem preparar-nos para a realidade e os desafios de amanhã. Contudo, a previsão das exigências de mão-de-obra não é uma ciência exacta. Existe uma considerável dúvida quanto à praticabilidade e justeza de tais previsões. Os métodos correntemente utilizados para o cálculo das necessidades de formação a médio e longo prazo tornam-se limitados quanto à sua certeza empírica e oferecem, na melhor das hipóteses, uma avaliação marginal credível".

Não pretendendo prolongar demasiado a listagem das múltiplas posições críticas colocadas à teoria do capital humano nos anos 90, passaremos a apresentar um resumo das mesmas e que são comuns a vários autores:

a) Dificuldade em quantificar ou "medir" a contribuição da educação para o desenvolvimento: quais os indicadores fiáveis a 
utilizar? Qual a porção de desenvolvimento que se deve à educação e a porção devida a outros factores?

b) Despesas com educação: consumo ou investimento? Esta crítica assenta no facto de não se considerar correcto tratar todas as despesas em educação como investimento, porque, de facto, uma porção de tais despesas é de consumo. O ponto principal é que, ignorando a componente consumo das despesas de educação e, portanto, considerando-as todas despesas de investimento, os investigadores subvalorizam a taxa de retorno dos investimentos educacionais.

c) O problema das capacidades: os críticos da teoria do capital humano duvidam que o diferencial de rendimento seja somente ou primariamente o resultado de educação adicional. Referem que "outras coisas" podem influir neste resultado.

Entre outras sugerem: capacidades inatas (Q.I.), auto-disciplina, motivação e outras características pessoais;

A crítica à abordagem "Custo - Benefício" ou "Taxa de Retorno", utilizada por muitos teóricos do capital humano, na década de 70, está relacionada com a questão anterior. Aquela abordagem tem por fundamento o facto da educação (formal e não formal) como uma forma de investimento em capital humano, que produz benefícios através do aumento da produtividade. Ora, as críticas feitas a esta abordagem questionam se os benefícios sociais da educação serão adequadamente medidos pelas diferenças salariais entre os que receberam determinado nível de educação e os que a não receberam. E quanto é que das diferenças salariais é devida à educação e a outros factores, como a aptidão, capacidade e origem socioeconómica?

d) As "hipóteses selectivas": sugerem que a educação afecta os rendimentos, não primariamente através da alteração da produtividade no mercado de trabalho dos estudantes, mas classificando e rotulando-os de tal modo a determinar a sua colocação a nível dos empregos e, portanto, dos seus rendimentos. A credencial torna-se, assim, um bilhete para a admissão aos empregos de nível mais elevado e mais bem pagos, onde as oportunidades para maior formação e promoção são melhores.

e) A teoria do capital humano é reducionista: o trabalho constitui muito mais que um factor de produção: propicia criatividade, mobiliza energias sociais, preserva a identidade da comunidade, desenvolve solidariedade, utiliza a experiência organizacional e o 
saber popular para satisfazer necessidades individuais e colectivas. O trabalho tem, pois, uma dimensão qualitativa que não pode explicar-se por modelos instrumentais de análise nem por cálculos econométricos de funções de produção.

A este propósito Max-Neef (1994: 107), por exemplo, afirma que a teoria do capital humano, para além de poder ser contestada no plano ético, contém um sofisma ideológico mercê do qual os trabalhadores também aparecem, de certa forma, como capitalistas. A teoria do capital humano reduz o trabalho humano à condição de capital acumulável, mediante investimentos em educação e formação.

Finalmente, os neomarxistas não rejeitando a noção de que a escolaridade afecta a produtividade dos trabalhadores, sustentam que a escolaridade a influencia muito diferentemente do que estabelecem as hipóteses colocadas pela teoria do capital humano. Referem que a função da escolaridade - do investimento em capital humano - é inculcar certas atitudes e valores "apropriados" (mais especificamente, o sistema capitalista precisa de trabalhadores que se submetam aos sistemas hierárquicos de autoridade e controlo, aceitem uma estrutura de recompensas económicas desiguais e respondam positivamente aos mecanismos de incentivos através dos quais as empresas extraem deles trabalho útil) que são consistentes e tendem a manter e perpetuar o sistema capitalista. As repercussões da educação no aumento da produtividade dos trabalhadores e, por consequência, no crescimento económico, não é uma relação verdadeira, pois defendem que há sistemas económicos alternativos que são potencialmente mais produtivos do que o capitalismo. O problema, de acordo com os marxistas, é que os teóricos do capital humano só tomam em consideração o impacto da educação sobre as capacidades dos trabalhadores e a produtividade e passam por cima da função da "reprodução social" da escolarização. Colocam a questão: quanto crescimento poderia ocorrer num sistema económico alternativo baseado na criatividade individual e autonomia, em oposição à subserviência e conformidade?

Não obstante toda as críticas feitas à teoria do capital humano e às fraquezas que ela encerra, somos dos que consideram da maior pertinência essa teoria na actualidade, embora também defendamos que 
existem limitações e requisitos para que os investimentos no capital humano se reflictam no desenvolvimento.

Perfilhamos, assim, as teses avançadas pelos novos modelos de crescimento endógeno, de acordo com os quais, como antes se expôs, o capital humano é um input produtivo que se encontra correlacionado com o crescimento económico sobretudo através da capacidade de inovação da economia - ele é um factor crítico para a sustentação dessa capacidade de inovação (não é possível inovar se não existirem recursos humanos bem preparados).

Contudo, achamos também que a educação, por si só, não pode ser vista como um instrumento de desenvolvimento. Para que tal aconteça, torna-se necessário que obedeça, entre outros, a determinados requisitos:

- Generalização da educação - alargamento da educação ao maior número possível de pessoas; aumento do número de anos de escolaridade obrigatória. É de evitar que a educação seja "apropriada" por um conjunto restrito de pessoas.

- Carácter endógeno - a educação deve ter em vista a valorização dos recursos e a identidade local (inovação curricular e aproximação dos conteúdos à realidade). Deve fornecer aos autóctones um conjunto de conhecimentos e instrumentos que lhes permitam fazer uma avaliação correcta dos recursos e necessidades da região e exercer um poder crítico sobre a realidade circundante.

- Diversificação da educação - a diversificação das formações oferecidas e a criação de novas competências são uma forma de resposta às novas exigências que a competitividade global e a tendência para a flexibilização impõem.

- Abertura da escola ao exterior - a escola deve manter um diálogo permanente com a comunidade envolvente: com as famílias, autarquias, sindicatos, empresas, etc.

- Educação permanente, formação profissional e contínua imprescindíveis devido à desactualização e obsolescência rápida e constante dos conhecimentos.

Em suma: defendemos que a educação, por si só, não pode ser considerada um instrumento de desenvolvimento; não é panaceia para 
todos os problemas de desenvolvimento das regiões: é um factor muito importante, de um conjunto variado de condições que determina a produtividade e a competitividade económica.

A perspectiva de sobreestimação dos efeitos da educação subscrita por muitos autores é, em nossa opinião, ingénua e perigosa, porque ignora outras condições necessárias que possibilitam a maximização desses efeitos.

Assim, o método que utiliza um único factor para melhorar a produtividade - aumentar os níveis educativos - distorce as políticas tanto nacionais como sectoriais, conduzindo-as por caminhos que dificilmente serão capazes de melhorar a produtividade nacional.

A educação, para além da obediência a requisitos fundamentais como os antes apontados e só associada a outras condições ou factores complementares é que poderá proporcionar benefícios para o desenvolvimento. Se os requisitos complementares não se verificam, as repercussões apenas serão de carácter nominal. Outras mudanças são necessárias para conseguir que as ambições de melhorias económicas e sociais se tornem realidade.

Algumas dessas condições complementares necessárias são:

a) Novos métodos de organização do trabalho - permitem beneficiar da maior capacidade produtiva dos trabalhadores instruídos (constituição de equipas de trabalho e outros métodos participativos que permitam que os trabalhadores utilizem o seu critério para tomar decisões e que apoiem tais oportunidades com a informação, os incentivos e a responsabilidade intrínsecos a tais métodos. Em muitos sentidos, estas novas formas de organização laboral baseiam-se em que os trabalhadores tenham a oportunidade de tomar decisões num ambiente rico em informação, provavelmente a área de maior potencial para que os trabalhadores instruídos possam melhorar a produtividade da empresa.

b) Novos métodos de gestão - a produtividade e a inovação relacionam-se ainda no que se refere ao modelo de gestão. Novos métodos de gestão que apoiem medidas de produção que fomentem a participação dos trabalhadores - práticas de gestão flexíveis viradas para a organização do trabalho em equipa, maior envolvimento dos trabalhadores menos qualificados, rotação dos trabalhadores e horizontalização das estruturas de gestão. Para além disso, devem integrar-se mais as áreas de investigação, 
formação, desenvolvimento de produtos, marketing, produção e financiamento.

c) $O$ "capital social " - a estratégia de desenvolvimento económico de cada país depende não só dos factores tangíveis (esforço de investimento, qualificação dos recursos humanos e a dotação de recursos naturais), mas também é influenciada, e muitas vezes de uma forma decisiva, por factores de ordem cultural e social. Entre esses factores contam-se os vínculos morais de confiança, a predisposição para cooperar e os princípios e valores éticos dominantes em cada sociedade - um conjunto de "activos" intangíveis designados por "capital social". Estudos empíricos demonstram a correlação positiva existente entre o aumento do índice de confiança e o aumento do Produto Interno Bruto (PIB), ou seja, do crescimento económico. Estas evidências sugerem que as políticas públicas devem assumir uma atitude que procure promover o investimento em "capital social".

\section{NOTAS}

\footnotetext{
${ }^{1}$ Uma das passagens clássicas de Smith (1723-1790) no livro I Cap. 10, de $A$ Riqueza das Nações (1776), é a seguinte: "Um homem educado à custa de muito esforço e tempo para qualquer emprego que exige destreza e qualificações especiais pode ser comparado a uma daquelas máquinas caras. O trabalho que ele aprende a realizar, como será de esperar, acima dos salários habituais da mão-de-obra comum, compensar-lhe-á todo o custo da sua educação, com, pelo menos, os lucros habituais de um capital igualmente valioso".

2 J. Suart Mill, em 1848, quase um século depois da obra de Smith, na sua exposição sobre a economia política clássica retoma o pensamento de Smith de forma mais contundente: "Para o propósito de alterar os hábitos da classe trabalhadora [...] a primeira coisa necessária é uma eficaz educação nacional das crianças da classe trabalhadora. Pode-se afirmar sem hesitação que o objectivo de toda a formação intelectual para a massa das pessoas deveria ser o cultivo do bom-senso; o torná-las aptas a formular um julgamento sadio das circunstâncias que as cercam, tudo o que se pode acrescentar a isso, no domínio intelectual, é sobretudo decorativo".

${ }^{3}$ Um século mais tarde que Smith, Alfred Marshall também escrevia: "Os salários e os rendimentos do trabalho assemelham-se ao juro do capital, porque há uma
} 
correspondência geral entre os factores que determinam os preços da oferta do capital humano; o que leva um homem a acumular capital humano na educação do seu filho é equivalente ao que o leva a acumular capital físico para o seu filho" (Marshal, 1890).

${ }^{4}$ Entre estes estudos, destacam-se os de Barro (1991), Levine e Renelt (1992), Easterly e Rebelo (1993), Sala-I-Martin (1994) e de Barro e Sala - I - Martin (1995).

5 Lau, L., Jaminson e Louat (1991) utilizam dados anuais sobre ratios de matrícula para estimar séries temporais dos stocks totais do nível de escolaridade para a população em idade activa. Maddinson (1991) apresenta também uma estimativa para o stock de capital humano, traduzida pelos "anos de escolaridade dos indivíduos com idades compreendidas entre os 15 e os 64 anos".

${ }^{6}$ Capital Humano, medido pela taxa de escolaridade no ensino secundário relativa ao período inicial da amostra, 1960. Crescimento económico quantificado pelo crescimento do Produto Interno Bruto (PIB), numa base per capita.

${ }^{7}$ Stock de capital humano medido pelo nível de escolaridade passada.

${ }^{8}$ A capacidade de inovação duma economia ou stock de conhecimento é consubstanciada normalmente no conjunto, passado e presente, de conhecimentos detidos pela economia e que possibilitam a emergência de inovações economicamente relevantes.

${ }^{9}$ Os efeitos internos restringem-se normalmente ao indivíduo que detém o capital humano (por exemplo, o impacto do nível de escolaridade, de formação ou de experiência profissional nos rendimentos do indivíduo). Em contrapartida, os efeitos externos envolvem grupos de indivíduos, a sociedade e mesmo conjunto de países, podendo ser empiricamente observáveis através, por exemplo, da relação entre o nível de escolaridade médio da população de uma determinada nação e a performance de crescimento da mesma (crescimento anual médio do PIB, por exemplo).

10 Por exemplo, Bartel (1991) descobriu uma relação positiva entre a implementação de programas de formação e o crescimento da produtividade do trabalho, não só a nível individual, mas também a nível organizacional. Ainda Bartel (1991) demonstrou que a educação tem um efeito positivo e significativo no crescimento salarial que traduz uma taxa de retorno de pelo menos $13 \%$.

11 De acordo com o modelo neoclássico tradicional de Solow, o progresso tecnológico é exógeno, algo "caído do céu" e é único motor do crescimento, não havendo lugar para intervenção do governo para influenciar a taxa de crescimento económico. 


\section{BIBLIOGRAFIA}

AZEVEDO, J. (1994), "Educação e Desenvolvimento: uma viagem à procura de novos horizontes", Revista Colóquio / Educação e Sociedade, $\mathrm{n}^{\circ}$ 6, Lisboa, F C G, pp. 133-158.

AZEVEDO, J. (1999a), “O Fracasso das Reformas do Ensino”, Porto, Jornal Público, 11 de Julho 1998, pp. 2-4.

BARATA, J. P. M. e AMBRÓSIO, T. (1988), Desafios e Limites da Modernização, Lisboa, IED.

BARRO, R.(1991), "Economic growth in a cross-section of countries", The Quartely Journal of Economics, vol. CVI, 2 pp. 407-443.

BENHABIB, J. e SPIEGEL, M. (1994), "The role of human capital in economic development: evidence from aggregate cross-country data", Journal of Monetary Economic, 33, pp. 143-173.

BLAUG, M. (1972), An introduction to the economics of education, New York, s. Ed.

BOUCHARD, P. (1999), Some myths about human capital, Montreal, Concordia University, pp. 1-12.

BURNETT, N.; MARBLE, K. e PATRINOS, A. (1995), “Estabelecendo prioridades de investimento na educação", Revista Finanças e Desenvolvimento, vol. 15, $n^{\circ}$ 4, Rio de Janeiro, Fundação Getúlio Vargas, pp. 142-144

DI PAOLA, R.; BERGÉS, M. e RODRÍGUEZ, E. (1993), Diferencias de ingresso entre Jefes de Família en la Ciudad de Mar del Plata. Un enfoque de la Teoria del Capital Humano, Plata, Asociación Argentina de Economia Política, pp. 1-13.

FITZSIMONS, P. (1997), Human capital theory and education, Auckland, Auckland University, pp. 1-5.

FRIGOTTO, G. (1989), A Produtividade de Escola Improdutiva, S. Paulo, Cortez Editora.

GARCIA DE DIEGO, L. (1975), "La economía de la educación. Visión general”, Revista de Educación, $\mathrm{n}^{\circ}$ 236-237, pp. 5-14.

HYDE, A. (1999), Notes on Human Capital, Newark, The State University of New Jersey, pp. 1-5.

LUCAS, R. (1993), “Making a miracle”, Econometrica, vol. 61, № 2, pp. 251-272.

MAX-NEEF, M. A. (1994), Desarrollo a Escala Humana, Barcelona, Icaria Editorial, S.A.

RODRIGUES, M. J. (1992), O Sistema de emprego em Portugal. Crise e mutações, Lisboa, Publicações D. Quixote.

SARUP, M. (1980), Marxismo e educação, Rio de Janeiro, Zahar Editores. 
SCHULTZ, T. (1993), "The economic importance of human capital in modernization", Education Economics, vol. I, No 1, pp. 13-19.

SCHULTZ, T. (1993), "The economic importance of human capital in modernization”, Education Economics, vol. I, No 1, pp. 13-19.

STOER et al. (1990), "O Novo Vocacionalismo na Política Educativa em Portugal e a Reconstrução da Lógica da Acumulação”, Revista Crítica de Ciências Sociais, $\mathrm{n}^{\mathrm{o}} 29$, pp. 11-53.

TEIXEIRA, A. (1999), Capital humano e Capacidade de inovação. Contributos para o estudo do crescimento económico português, 1960-1991, Lisboa, Conselho Económico e Social.

TEODORO, A. (1994), Política Educativa em Portugal, Lisboa, Bertrand Editora. 